\title{
Volcano Blind Map as a Solution to Increase the Disaster Mitigation Capability of Merapi Mountain of Blind Students in SLBN 1 Sleman
}

\author{
Kristi Dese Imanuel Adi Papa Yohanes ${ }^{1}$, Alfiatus Zulfa ${ }^{2}$, Ashabul Kahfi ${ }^{3}$, Andi Irwan \\ Benardi ${ }^{4}$ \\ \{krisjohannes89@students.unnes.ac.id ${ }^{1}$,zulfadien27@gmail.com², \\ ashabulkahfi261@gmail.com ${ }^{3}$ \} \\ 1,2,3,4 Universitas Negeri Semarang, Indonesia
}

\begin{abstract}
This activity was carried out with the aim of knowing 1) the level of knowledge of blind students in SLBN 1 Sleman on spatial conditions in their schools, 2) the level of knowledge of blind students in SLBN 1 Sleman on disaster risk in their schools, and 3) how to increase the capacity of students and teachers in reduce the risk of disaster. The method that we use in this activity is an approach with the method of Participatory Action and Learning System (PALS) which places SLBN 1 Sleman class students and teachers as the subject and object directly in the process of awareness, capacity building, mentoring to institutionalization. We create learning media in the form of a Volcano Disaster Mitigation Blind Map (VODIMB) model that aims to improve spatial knowledge and mitigation of blind students. Based on the activities we have done at the school, it is known that the learning media VODIMB model consisting of zoning zones of Merapi eruption hazard and school maps can help improve spatial knowledge, and disaster mitigation for blind students in SLBN 1 Sleman.
\end{abstract}

Keywords: Mount Merapi, Blind Map, Blind Students, Mitigation

\section{Introduction}

Mount Merapi is one of the most active volcanoes in the world. Almost every period of Mount Merapi erupts. "Secara rata-rata gunung Merapi meletus dalam siklus pendek yang terjadi setiap antara 2-5 tahun, sedangkan siklus menengah setiap 5-7 tahun "[1]. The eruption activity of Mount Merapi with its characteristic emits incandescent lava and hot clouds, without forming a caldera (crater). Geographically, Mount Merapi is located at 7॰ south latitude and $110^{\circ}$ longitude. The condition of Mount Merapi, which is still active until now, certainly requires preparedness from all elements of the community in the Merapi eruption radius zone and the government in understanding each development of its volcanism.

SLB Negeri 1 Sleman as a school that has blind students based on the zoning map of the Merapi eruption hazard issued by the National Disaster Management Agency (BNPB) is located at a radius of $12 \mathrm{~km}$ from Mount Merapi. Gradual volcanic activity causes SLBN 1 Sleman not to be closed immediately. When phreatic eruptions occur, students in SLBN 1 Sleman, especially blind students experience panic and confusion because they do not recognize the space and environment properly. The limitations of learning media, especially those related to the disaster mitigation map media of the Merapi eruption, have become one of the factors of students' unpreparedness in facing the disaster of the Merapi eruption. 
For your information, "anak tunanetra merupakan individu yang indera penglihatannya rusak dan mengalami keterbatasan penglihatan. Akibat hambatan itu mengalami ketidakmampuan penglihatan sehingga tidak berfungsi sebagai saluran penerima informasi secara visual setelah dikoreksi dan membutuhkan layanan pendidikan khusus" (Hallahan and Kauffman [2]). So far, the development of learning media for blind students is still limited. This is one of the problems in inclusive education in Indonesia.

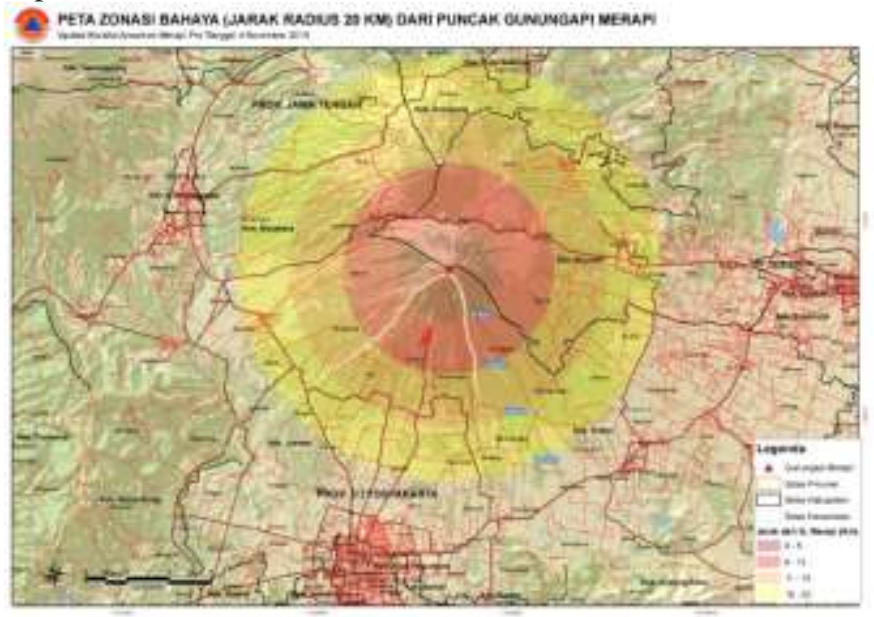

Fig. 1. Map of Mount Merapi Hazard Zonation(BNPB, 2010)

"Siswa tunanetra mempunyai potensi akademis sama dengan siswa yang memiliki kondisi fisik normal. Hal yang membedakan antara keduanya hanyalah karena siswa tunanera memiliki keterbatasan dalam penglihatan yang menyulitkan mereka untuk mengembangkan diri" [3]. Therefore, it is a necessity for every provider of inclusive education to place educational media as an important component of the education system that it organizes. Based on the description of the problems above, a structured and sustainable disaster mitigation education activity is needed and is equipped with appropriate learning media. So, this activity was carried out with the aim to determine the level of understanding of disaster mitigation of blind students in SLB Negeri 1 Sleman and how to improve students' understanding of spatial conditions and disaster mitigation using the Volcano Disaster Mitigation Blind Map learning media model. 


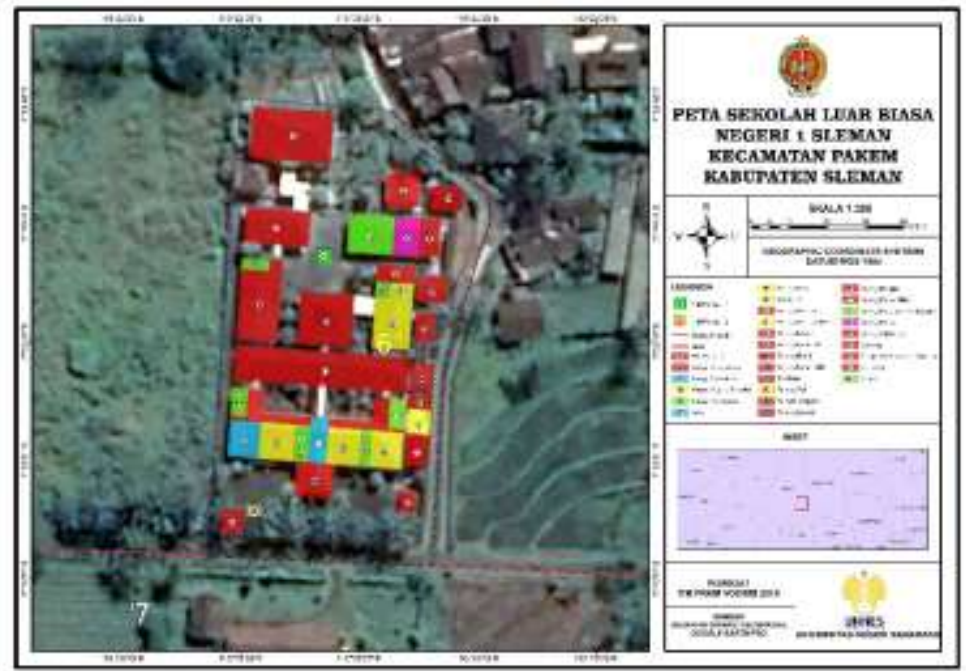

Fig. 2. Map of SLBN 1 Sleman

\section{Research Method}

This activity was held at SLB Negeri 1 Sleman in Pakembinangun Village, Pakem District, Sleman Regency, Yogyakarta Special Province. The methodology used in this activity is the PALS (Participatory Active Learning System) method. So the target of the implementation of the PKM-M program is training that can improve the knowledge capacity of disaster mitigation for blind students in SLBN 1 Sleman. This method makes the target community "sebagai subjek sekaligus objek dalam kegiatan pengabdian melalui berbagai bentuk pendidikan, pelatihan, penyuluhan, serta pembinaan dan pendampingan" [4]. According to Mardana (2017: 3), "tahapan dalam metode PALS meliputi tahap penyadaran, tahap pengkapasitasan, serta tahap pelembagaan" [5]. The sample used in this study was 15 students who were analyzed comparatively to compare students' knowledge before and after service. The instrument used was a questionnaire in the form of written and oral questions.

\section{Result and Discussion}

\subsection{General Overview of Target Communities}

SLB Negeri 1 Sleman Regency is one of the outstanding schools in Yogyakarta. This school is located on Jalan Kaliurang km. 17.5 Pakem Subdistrict, Sleman Regency, Special Region of Yogyakarta, and was built in 2006 based on School Establishment Certificate number 208 / KEP / 2006 dated 7 November 2007. SLB Negeri 1 Sleman has 109 students, and this school provides education services for students with special needs include blind people, hearing impaired, mentally retarded, disabled, and autistic and are already equipped with adequate supporting facilities, except for disaster mitigation learning media that are not yet available. 


\subsection{Making a Volcano Blind Map Learning Media}

The absence of learning media for disaster mitigation education for Children with Special Needs (ABK) such as students with visual impairments in the SLB 1 Sleman. This condition encouraged the PKM-M team to collaborate with blind visual instructors to produce learning media for disaster mitigation education in the eruption of Mount Merapi which created the spatial knowledge of blind students. References used include the Basic Cartography Book which contains the concept and effectiveness of maps as space learning media and the Indonesian Braille Symbol book from Sugiarti which explains the effectiveness of Braille letters as written communication media for the visually impaired.

According to Setyowati, et al., [6] peta memungkinkan manusia melakukan pengamatan ruang secara lebih luas pada suatu daerah. Jika peta itu dibuat dengan baik, peta menjadi alat yang baik untuk berbagai kepentingan seperti pelaporan, peraga, analisis, dan pemahaman tentang ruang. The effectiveness of maps as a space for information media is adjusted to the conditions and needs of blind students and combined with braille which is a written communication medium for blind children.

The Volcano Blind Map (VODIMB) product is generated based on the experimental stages so as to produce learning media with new tools and materials and methods. Therefore VODIMB gets the opportunity to get Copyright Patent Rights. Therefore, the PKM-M team has registered a patent document entitled "The 3-Dimensional Volcano Disaster Mitigation Blind Map" in the HKI LPPM center of Universitas Negeri Semarang to be registered with the Patent Directorate of the Directorate General of Intellectual Property Rights of the Republic of Indonesia.

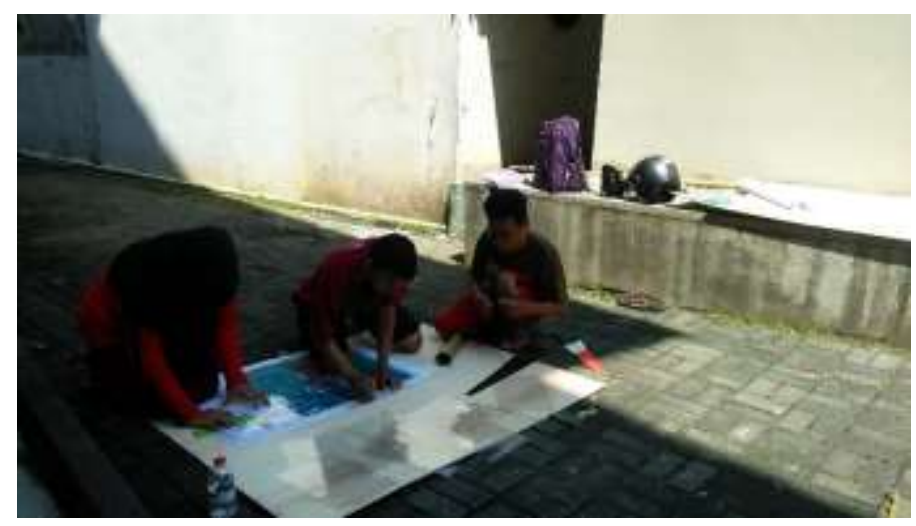

Fig. 3. Documentation of Making Learning Media

\subsection{Stages of Implementing Disaster Mitigation Training}

Training to improve spatial knowledge through the Volcano Blind Map model for blind students in SLBN 1 Sleman. The training of the Volcano Blind Map program aims to provide training for blind students to build their knowledge of the evacuation route, if later a disaster erupts Mount Merapi, they can evacuate themselves. Training from the Volcano Blind Map program. Not only aimed at blind students, the teachers at SLBN 1 Sleman were also included, which was a form of Team's seriousness to make the Blind Map Volcano program not stop in place (sustainable). The training that the Team gave to blind students in SLBN 1 Sleman, the 
concept of a map of the blind who had more control over the techniques of reading Braille sentences.

The evaluation of the Volcano Blind Map program that has been carried out shows that there is an increase in students spatial knowledge of the evacuation route and most of the visually impaired students at SLB 1 Sleman understand the disaster mitigation education of Mount Merapi eruption. From the results of dedication, blind students at SLBN 1 Sleman claimed to never know what the shape of Mount itself was like, even students did not know if their school was in a dangerous radius of Mount Merapi eruption and they did not understand the flow of self-evacuation when Mount Merapi erupted. One example, student A, after being trained in the class III SLB program, now able to understand the flow of self-evacuation during the eruption of Mount Merapi, the students knew when an earthquake occurred, steps to take include protecting the head with a bag, or hiding under a table, and most importantly he knows the path students must pass to evacuate themselves.

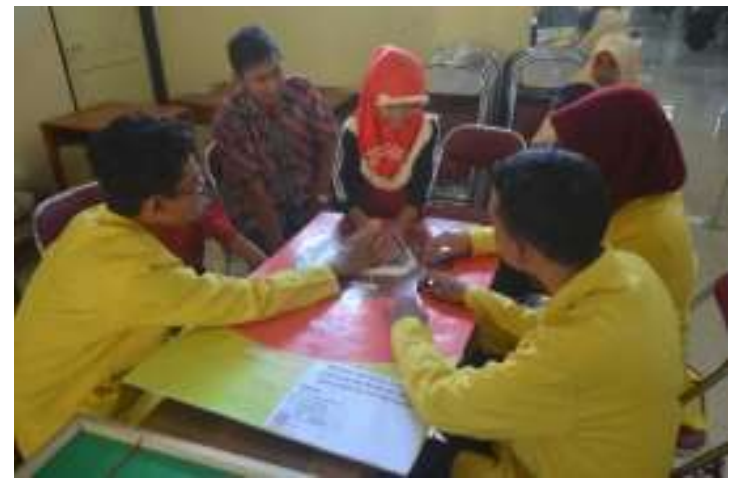

Fig. 4. Provide Training in Reading Volcano Blind Map

\subsection{Potential for Program Sustainability}

The collaboration development began with an agreement between the PKM-M team and blind class teachers to develop disaster mitigation learning media for the eruption of Mount Merapi for blind students based on Volcano Blind Map. The Principal of SLBN 1 Sleman included these development activities into the development team's program of continuous competence. The first activity carried out was training for blind class teachers to create Volcano Blind Map media with new themes. During the training the team was given input regarding learning strategies for blind students based on the experience of teaching teachers. Through a series of training stages, a continuous organization was developed to develop the organization's program, named the VODIMB Development Team.

\section{Conclusion}

(1) The disaster mitigation training program provided through this program has improved spatial capacity, mitigation and disaster preparedness for blind students in SLBN 1 Sleman. (2) Blind class teachers and do not rule out the possibility of other teachers becoming more innovative in creating learning media. (3) The creation of cooperation in the implementation of the program through MoA and the ratification of the Sustainable Competency Development 
Team (PKB) between SLBN 1 Sleman and the Universitas Negeri Semarang PKM-M team. (4) Learning media produced through the Volcano Blind Map program are innovative media in supporting the improvement of disaster mitigation capabilities of the Merapi eruption for blind students.

\section{References}

[1] S. R. Wilujeng, "Meningkatkan Kualitas kehidupan berbangsa melalui budaya Demokrasi," HUMANIKA, vol. 19, no. 1, pp. 145-157, 2014.

[2] R. R. Handoyo, "Pengembangan Komunikasi Anak Tunanetra Dalam Permainan Kooperatif Traditional," JPK (Jurnal Pendidik. Khusus), vol. 12, no. 2, pp. 96-111, 2016.

[3] S. F. Akbar, "Pengembangan Media Power Point Berbraile Mata Pelajaran IPS Materi Lingkungan Untuk Siswa Tunanetra Di Sekolah Luar Biasa Kota Semarang Tahun 2014," Edu Geogr., vol. 3, no. 8, 2015.

[4] I. B. J. Swasta, I. W. Karyasa, I. W. Rai, and I. P. Suardika, "Implementasi Program Ipteks Bagi Wilayah di Kecamatan Kubutambahan, Kabupaten Buleleng Tahun 2010," J. Ngayah, vol. 2, no. 2, 2011.

[5] I. B. P. Mardana, "Ipteks Bagi Wilayah (IBW) di Kecamatan Gerokgak," Widya Laksana, vol. 1, no. 1, pp. 1-11, 2017.

[6] D. L. Setyowati, A. I. Benardi, and S. Putro, "Kartografi Dasar," Ed. ke-1, Penerbit Ombak. Yogjakarta, 2014. 